\title{
MODEL OF FUNCTIONAL GOVERNING AND OPTIMAL ORGANIZATION OF FOREST SECTOR IN FEDERATION B-H
}

\section{Model funkcionalnog upravljanja i optimalne organizacije sektora šumarstva Federacije BiH}

\author{
Sabina Delić ${ }^{1}$, Dženan Bećirović ${ }^{1}$, Bruno Marić ${ }^{1}$, Amila Brajić ${ }^{1}$, \\ Senka Mutabdžija ${ }^{1}$
}

\begin{abstract}
In order to define functional model of governing of forest resources in F B-H, as well as efficient and effective organizational model of the forest enterprises, qualitative research has been conducted for the purposes of this paper. Through direct interviewing of all key forest policy decision makers in F B-H, opinions and attitudes about these questions were collected. Based on analysis of interest groups importance as well as influence and involvement in the process of creation of the functional forest governing model in F B-H - functional governing model has been proposed with clear emphasis of advantages concerning present model.

Principles of sustainable governing and management of forest resources, assurance of participative approach in the process of decision making and transparency were basis for definition of functional governing model for management of forest resources.

For provision of optimal model of organization of forest sector in F B-H, it has been crucial to define ecological, sociological, economical and other criteria, that user of forest resources should respect. The optimal number of organizational units, which manage forest resource on the territory of $\mathrm{F} \mathrm{B-H}$, depends from the achievement of the established criteria and real capacities for establishment of the enterprise. This would lead to further decentralization in management of forest resources in $\mathrm{F} \mathrm{B-H}$; that would have its positive effects.
\end{abstract}

Key words: model of functional governing, sustainable management, decentralization, participation, optimal organization

1 Faculty of Forestry, University of Sarajevo 


\section{INTRODUCTION - Uvod}

Bosnia and Herzegovina (hereinafter B-H) is administratively divided on two entities, Federation of B-H (hereinafter F B-H) and Republic of Srpska (hereinafter RS). Entities are responsible for politics of environmental protection and politics of natural resource management, which includes forest resources. With respect to ownership structure, $81 \%$ of B-H's forests are state owned and rest $19 \%$ are private owned forests. Administration of forests and forests land is under the jurisdiction of the owner and it consider activities such as supervision, control and planning of forest management. In realization of the rights based on forests and forest lands ownership, entities are represented by the entity Ministries for agriculture, water management and forestry.

Law on forests of F B-H (2002) prescribes that forests and forest land, owned by the State, are governed by the Federal Office for forests at the level of the entity while Cantonal offices are established at the level of each canton separately. Federal office transmit its duties to the cantonal offices which means that the owner (F B-H) loose the possibility of creating common forest policy and functional governing of forest resource. Ambiguously defined vertical coordination leads to the overlapping of duties and responsibilities that have significant consequences when it comes to the strategic planning by reducing the dominant influence of the owner.

Forest management duties and responsibilities are transferred by the contract from the Federal ministry of agriculture, water management and forestry to the Cantonal ministries responsible for forestry. Cantonal offices transfer forest management activities to the forest management enterprises (hereinafter FME), as legal entity established to conduct management activities at the state-owned forest on the territory of one canton. Nevertheless, forest management at the territory of the $F$ $\mathrm{B}-\mathrm{H}$ is faced with manifold problems mainly connected with the ineffective and inefficient organization of the forest sector of F B-H.

\section{MATERIALS AND METHODS - Materijal i metode}

With the aim of defining functional model for governing forest resources and optimal organizational model of forest sector in F B-H, qualitative research had been conducted in this paper. Opinions and attitudes of all important actors of forest policy in the F B-H on functional governing are gathered by face-to-face interviews. The questionnaire was consisted of 4 , both closed and open questions. Key actors for issues of governing forest resources in F B-H are as follows:

1. Public forest administration (PFA)

- Federal ministry of agriculture, water management and forestry (FMAWMF)

- Federal office for forestry (FOF)

- Cantonal offices for forestry (COF)

2. Non-governmental organizations (NGOs) 
- Local community (Association of Cities and Municipalities of F B-H ACMFB-H)

3. Professional associations

- Association of forestry engineers and technicians of F B-H (AFETFB$\mathrm{H})$

- $\quad$ Croatian forestry association (CFA)

4. Academic institution

- Faculty of Forestry University of Sarajevo (FoF)

With the aim of defining optimal organization of forest sector, interviews were conducted with the 22 interviewees from the identified interest groups:

1. Federal ministry of agriculture, water management and forestry (FMAWMF)

2. Federal office for forestry (FOF)

3. Cantonal ministries responsible for forestry (CMF)

4. Public forest enterprises (PFE)

5. Local community (Association of Cities and Municipalities of F B-H ACMFB-H)

6. Professional associations

- Association of forestry engineers and technicians of F B-H (AFETFB-H)

- Croatian forestry association (CFA)

7. Academic institution (FoF)

The questionnaire had two questions, open and closed one. For clarity and visibility, results are presented in the form of "advocate-opponent" matrix, and in the descriptive form. Influence and importance of identified interest groups have been taken into consideration in the drawing conclusions about the addressing issues of functional governing of forest resources and organization of forest sector in F B-H (JovIĆ and JovIĆ, 2010). Considering the previous, they have been divided into 4 groups.

- Stakeholders A (have large importance and influence and therefore they need to be involved in the process to the biggest extent possible).

- Stakeholders B (have large importance but small influence. Due to that, significant effort must be oriented toward improvement of their participation in the process).

- Stakeholders C (have small importance but big influence and therefore they can cause some drawbacks).

- Stakeholders D (have small importance and small influence which means that their interests can be satisfied through public information activities). 


\section{RESULTS AND DISCUSSION - Rezultati i diskusija}

\section{Model of functional governing of forest resources in the F B-H - Model funkcionalnog upravljanja šumskim resursima u FBiH}

Governing of the forests that include activities such as supervision, control, management planning of forest and forest land, whether they are state or private, belongs to the owner (SABADI, 1992). Federal Law on forest ${ }^{1}$ (2002) clearly prescribes the term forest ownership. State forests are owned by the Federation that is represented by the Federal Ministry of Agriculture, Water and Forestry (Article 44). State forests and forest lands are governed by the Federal office within the Federal Ministry and Cantonal office (Article 48). Such defined governing results with ambiguities, also confirmed in practice (DELIĆ, 2009). Law provides that the Federal ministry by the contract transfers forest management activities to the Cantonal ministries, and cantonal ministries through Cantonal offices assign activities to the public forest management enterprises (Article 49). In accordance with the Constitutional provisions, Federation can transfer governing in a certain degree to the Cantons, but this should not lead to a reduction in the influence of the dominant owner with respect to strategic governing. Defined relationship between the Federal office and Cantonal offices are not prescribed by the Law.

The establishment of the Federal office and the transfer of jurisdiction to the Cantonal offices led to the separation of the ownership and governing functions, which is a major weakness of the organizational structure of the State' governing system. In such organization, problems arise regarding enforcement of the owner's decisions because there is no developed system of direct vertical coordination between these two levels. Since there are different levels of executive authority, responsibility and duty appointed directors of forest office at federal and cantonal levels is geared toward ministries that appointed them, rather than to each other (in a vertical sense). In this governing model there is no possibility of centralization in the creation of the common forest policy, and also effective implementation of political measures is not possible because of overlapping in jurisdiction and accountability between these institutions.

Existing initiatives for the adoption of the new Law on forests proposes improvements in addressing issues of forest governing in the $\mathrm{F} \mathrm{B}-\mathrm{H}$, taking into account the need to eliminate evident and previously stated problems and jurisdiction of institutions in the implementation of the Law on forest and the actual (current) model of forest governing.

With the aim of defining functional model of forest resources governing, research gave the attitudes of identified interest groups. Based on their influence and

\footnotetext{
${ }^{1}$ This law was abrogated by the Constitutional Court in 2009, then temporary Regulation on forests was adopted and also it expired. Procedures of proclamation new Law is pending.
} 
importance in solving this issue, they are grouped and presented in the following matrix (Jovıć and Jovıć, 2010):

\section{STAKEHOLDER , A $^{6}$ \\ FMAWMF \\ FOF \\ STAKEHOLDER, $\mathrm{CC}^{\text {“ }}$ \\ $\mathrm{COF}$ \\ ACMFB-H}

STAKEHOLDER ,B“

FoF

AFETFB-H and CFA

STAKEHOLDER ,D“6

Results showed that the majority of interviewees are agreeable about defining the term of forest governing which includes a number of measures and instruments to achieve sustainable forest management (Table 1). Most of them highlighted the need to adopt legislation which would regulate governing and management of the forest. Governing is connected with the ownership and the owner has rights and duties related to governing and managing.

Table 1. Respondents' attitudes towards defining of forest resources governing Tabela 1. Stavovi ispitanika o definisanju upravljanja šumskim resursima

\begin{tabular}{|c|c|c|c|}
\hline INSTITUTION & POSITIVE & INDECISIVE & NEGATIVE \\
\hline \multirow{10}{*}{$\begin{array}{l}\text { Public forest } \\
\text { administration }\end{array}$} & FMAWMF & & \\
\hline & FOF & & \\
\hline & & & COFUSK \\
\hline & COFTK & & \\
\hline & COFZD & & \\
\hline & COFSBK & & \\
\hline & COFZH & & \\
\hline & COFHNK & & \\
\hline & COFP & & \\
\hline & COFS & & \\
\hline \multirow{2}{*}{$\begin{array}{l}\text { Professional } \\
\text { associations }\end{array}$} & & AFETFB-H & \\
\hline & CFA & & \\
\hline Academic institution & FoF & & \\
\hline $\begin{array}{c}\text { Non-governmental } \\
\text { organisations } \\
\end{array}$ & ACMFB-H & & \\
\hline
\end{tabular}

Results showed that the majority of interviewees are agreeable about the fact that functional governing of forest resources implies effective and efficient governing of the forest resources (Table 2). Effective governing means ensuring sustainable forest management in accordance with the demands of society, efficient governing means achieving financial benefits and positive business of forest enterprises. 
Representative of forests owner, who showed hesitancy, indicates the need to pay rent for using „better“ forests, in order to secure sustainable managing of the „worse“ forests.

Table 2. Respondents' attitudes towards definition of functional governing of forest resources Tabela 2. Stavovi ispitanika o definiciji funkcionalnog upravljanja šumskim resursima

\begin{tabular}{|c|c|c|c|}
\hline INSTITUTION & POSITIVE & INDECISIVE & NEGATIVE \\
\hline \multirow{10}{*}{$\begin{array}{l}\text { Public forest } \\
\text { administration }\end{array}$} & FMAWMF & & \\
\hline & & FOF & \\
\hline & COFUSK & & \\
\hline & COFTK & & \\
\hline & COFZD & & \\
\hline & COFSBK & & \\
\hline & $\mathrm{COFZH}$ & & \\
\hline & COFHNK & & \\
\hline & COFP & & \\
\hline & COFS & & \\
\hline \multirow{2}{*}{$\begin{array}{l}\text { Professional } \\
\text { associations }\end{array}$} & AFETFB-H & & \\
\hline & CFA & & \\
\hline Academic institution & FoF & & \\
\hline $\begin{array}{l}\text { Non-governmental } \\
\text { organisations }\end{array}$ & ACMFB-H & & \\
\hline
\end{tabular}

Opinion about the current model of forest resources governing is negative. What is important is that different interest groups are compatible about that. In the explanation of their views, respondents pointed out the following facts:

- Separation of governing and ownership function (governing is transferred at the cantonal level)

- Decentralisation in the forest policy and adoption of policy measures

- Ambiguous attitude and expectations of the owner

- Owner loses jurisdiction and has no concrete benefits from the resource

- Unclear delineation of jurisdiction of the Federal office and Cantonal offices

- Weak coordination between Federal office and Cantonal offices and their irresponsibility

- Unclear separated control, administrative and economic functions,

- The problem of Cantonal offices and Federal office under the Ministry (the dependence of the current attitude of the Minister)

- The problems regarding the inspection activities, etc.

From this arise fact on serious consideration of key issue towards forest resources governing. When it comes to the proposal about the functional model of 
governing forest resources, among all listed options, opinion that the best solution is to have independent Federal office for forestry out of Federal ministry for agriculture, water management and forestry with the cantonal departments (offices). This idea is supported mostly by the representatives from COF, AFET, CFA and FoF and surprisingly - by the representative of the FMAWMF. For the current model voted one COF only. FOF suggested proposal which was not at the given list. Representative of this institution had suggested that FOF should be independent body but with the departments on the level of municipalities which have forests. Similar proposal is given by the ACMFB-H apropos they think that best solution is independent FOF out of the FMAWMF with departments according to the organizational needs. One COF suggested independent FOF and independent COFs.

\section{Model of optimal organisation of forest sector - Model optimalne organizacije šumarskog sektora}

According to the Law on forests of F B-H (2002.) and currently valid Regulation on forests FMAWMF transmit management of the state forest by the contract to the cantonal ministries. Cantonal office assigned management of forest and forest lands to the forest management enterprises. In the F B-H 8 independent public cantonal enterprises and 4 independent offices for management of forest units has been formed. Most cantonal enterprises includes more forest management areas (hereinafter FMA) and organisationally they are composed of several offices for management of forest units that do not have legal personality.

Based on this legal procurement, cantonal forest enterprises have different resource basis in terms of area, stock, increment, and quality and quantity of the timber. Besides of the natural resources, these enterprises differ by the human and material resources (DELIĆ, AVDIBEGović, 2009).

In the table 3 there is clear distinction between following referent indicators: total forest management area, area covered with the high forests, annual available cut, number of employees, realized volume and value of production per employee, and realized value added.

Since that existing FME were established at the cantonal level in accordance to the Law, it is obvious that their formation is not based on specific criteria. The business results and the inefficiency of some of them point out to the need for reorganization in order to improve the situation. In order to ensure the sustainable management of forest resources, forest users (FME) have to meet the principles and criteria for sustainable forest management (FIGURIĆ, 1996). Below is a review of sociological, economic and environmental criteria in accordance with the FSC Principles ${ }^{1 .}$

\footnotetext{
${ }^{1}$ Improved Pan-European Indicators for Sustainable Forest Management, MCPFE Expert Level Meeting, 2002, Vienna, Austria
} 
Table 3. Overview of productions' and operations' indicators of forest enterprises in the F B-H for the year 2009

Tabela 3. Pregled pokazatelja proizvodnje i poslovanja preduzeća šumarstva u FBiH u 2009.

\begin{tabular}{|c|c|c|c|c|c|c|c|c|c|}
\hline FME & 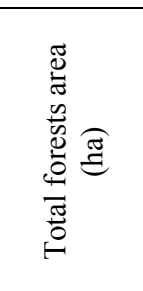 & 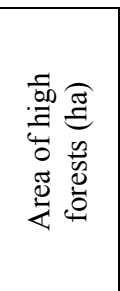 & 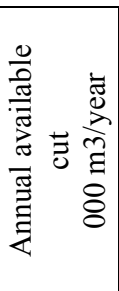 & 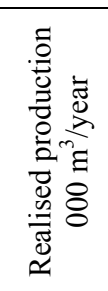 & 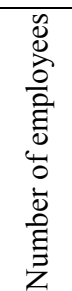 & 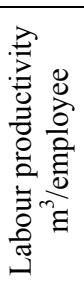 & 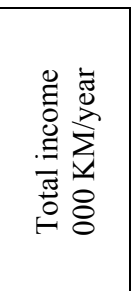 & 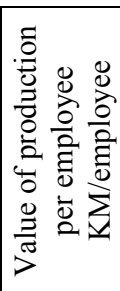 & 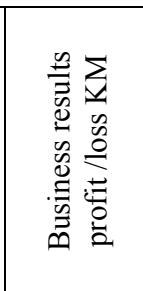 \\
\hline $\begin{array}{l}\text { Unsko-sanske } \\
\text { šume }\end{array}$ & 179.943 & 72.391 & 612,7 & 335,9 & 574 & 585 & $22.882,5$ & 39.865 & 77.673 \\
\hline Šume TK & 72.435 & 42.908 & 286,7 & 191,1 & 519 & 368 & $12.317,1$ & 23.732 & -254.273 \\
\hline $\begin{array}{c}\text { Šume ZE-DO } \\
\text { kantona }\end{array}$ & 195.901 & 127.057 & 747,9 & 355,6 & 955 & 372 & $27.876,2$ & 29.190 & -3.759 .499 \\
\hline $\begin{array}{c}\text { Šme Bosansko- } \\
\text { podrinjskog } \\
\text { kantona }\end{array}$ & 21.958 & 9.706 & 63,9 & 34,1 & 38 & 897 & $1.383,1$ & 36.398 & 24.268 \\
\hline$\underset{\substack{\text { Srednjobosanske } \\
\text { šume }}}{ }$ & 185.622 & 108.523 & 505,4 & 408,7 & 889 & 460 & $26.918,9$ & 30.280 & -1.684 .676 \\
\hline $\begin{array}{c}\text { Hercegovačko- } \\
\text { neretvanski } \\
\text { kanton }{ }^{1}\end{array}$ & 194.078 & 45.085 & 143,4 & n.a. & n.a. & n.a. & n.a & n.a. & n.a. \\
\hline Šume ZHŽ & 32.716 & 3.565 & 18,4 & 7,9 & 12 & 665 & 530,0 & 44.167 & 127.000 \\
\hline Sarajevo-šume & 70.746 & 34.752 & 199,7 & 142,7 & 476 & 300 & $12.902,4$ & 27.106 & -203.478 \\
\hline $\begin{array}{c}\text { Hercegbosanske } \\
\text { šume }\end{array}$ & 325.994 & 93.277 & 504,2 & 489,2 & 524 & 934 & $30.220,9$ & 57.674 & 1.213 .498 \\
\hline F B-H & 1.279 .393 & 537.264 & $3.08,1$ & $1.965,2$ & 3987 & 493 & $135.030,9$ & 33.868 & -4.459 .487 \\
\hline
\end{tabular}

Source: Information on forest management in the F B-H for the year 2009, FMAWMF

The most important sociological criteria are:

- Employment of local population

- Continuous education and professional training of its employees

- Permit to use drinkable water and other basic sociological services to the local population in accordance with existing regulations

- Ensuring the jobs in forestry only to the employees and contractors who have been trained in accordance with the legal provisions

- $\quad$ Ensuring employment conditions in accordance with the legislation of the B-H

- Ensuring assessment of the potential social impacts of forest management to the local communities

\footnotetext{
${ }^{1}$ Data on forest enterprises' business (offices for management of forest units) formed in the Canton were not available
} 
- Roads construction that affect both, forest management activities and development of the local community, especially mountain community

Economic criteria are:

- Encouraging the efficient use of multiple products and services from the forest to ensure economic viability and a wide range of ecological and sociological benefits

- In the use of forests should strive toward economic viability, while taking into account ecological, sociological and operational costs of production and securing the required investment to conserve productivity of the forest

- Forest management and marketing activities should encourage the optimal use and local manufacture of the diverse forest products

- Forest management should minimize waste associated with harvesting and production on the spot and avoid damage to other forest resources

- Strive towards strengthening and diversification of local economy, avoiding dependence on a single forest product

- Management activities has to recognize, maintain, and where possible improve the value of forest services and resources such as watersheds and fisheries.

- Utilization of the forest products must not exceed the permanently sustainable level (rational and sustainable management)

Ecological criteria are:

- Forest management need to conserve biological diversity, and its associated values, water resources, soil, unique and sensible ecosystems and landscapes, thus maintain the ecological functions and forest integrity

- Ecological functions and values need to stay intact, improved or restored

- Written instructions need to be prepared and applied to control erosion, minimize damage during harvesting, road construction, all other mechanical activities and protect water resources

- Management systems need to promote the development and adoption of environmentally friendly non chemical methods for combat against pest and strive to avoid the use of chemical pesticides.

Listed FSC principles are in accordance with improved indicators of sustainable forest management established by the expert at the MCPFE 2002 meeting in Vienna. Principles as such should be basis to define criteria for establishment of an undertaking as forest user in the F B-H. These criteria should be also the criteria for the formation of forest management area as basic unit which ensure ensure the rational and permanent forest management whose establishment should be based on expert elaboration. Minimum area for ensuring sustainable forest management is forest management area if meets given principles. After the identification of the interest groups, grouping based on their influence and importance in solving the issues of 
optimal organization of the forest sector is conducted and presented in the following matrix (Jović, JovIĆ, 2010):

\begin{tabular}{|c|c|}
\hline STAKEHOLDER ,A“ & STAKEHOLDER ,B“" \\
FMAWMF & FoF \\
FOF & AFETFB-H and CFA \\
CMF & \\
ACMFB-H & STAKEHOLDER ,D“ \\
STAKEHOLDER ,C“ & - \\
\hline Forest enterprises & \\
\hline
\end{tabular}

In order to meet criteria for sustainable forest management one part of the interviewees, who elaborate their opinion widely, thinks that economical, ecological and sociological criteria has to be defined. The other part of the respondents clearly shows the need to define the criteria, giving quantitative estimations regarding the minimum or optimum area for the management, timber volume, ratio between high and coppice forests, ratio between broadleaves and conifers, number of employees etc., while some believe that it is impossible to make such estimations due to the influence of many factors. Also, those who deal with this issue, and those who are better informed, have pointed to the existence of defined criteria by various international institutions. The concept of sustainable management is clearly defined within the MPCFE framework, the Helsinki criteria and FSC criteria. Such criteria have to be met for sustainable management of forest resources in a particular area. Meeting these criteria means condition for existence of the enterprise.

Attitudes of respondents regarding the optimal organization and the number of forest business entities at the all government levels are much differentiated both between different interest groups and between the same groups. The questionnaire offered the following options:

1. Forest management enterprises at the cantonal level (current status)

2. One enterprise in the F B-H (in a form of holding with daughter companies that have legal status)

3. One public Federal enterprise with cantonal departments (without legal status)

4. One or more enterprises at the cantonal level

5. Enterprise at the one FMA (with legal status)

6. One forest enterprise at the municipal level (municipal forest enterprises)

7. Other

For the current organization (enterprises at the cantonal level) voted some representatives of FME and one cantonal ministry. They believe that the current organization is good, the enterprises are currently doing well, and any further fragmentation would be harmful. Majority of respondents ( 7 of them) chose option 2. This option is supported mostly by the representatives from the Ministry, professional 
associations (AFETFB-H and CFA) and several representatives of the forest enterprises. What follows are ecplanations of respondents' views:

- Similar system has worked well in the past of B-H (SOUR: Šipad and Krivaja and OOUR)

- Possibility of more efficient control and forest protection

- Centralization with establishment of the hierarchy in the management

- Possibility of creativity and independence in order to achieve common interests

Five respondents think that the most suitable option is option of one or more enterprises at the cantonal level. This idea is supported mostly by the representatives from the owner and some directors of the FME. They explain its views as follows:

- Respecting the differences and specificity of cantonal economic conditions and necessity for the application of different solutions in forest management

- Efficiency in making and implementing decisions

- Decentralization of the forest management

Academic institutions suggested proposal which was not at the given list (other). Representative of this institution had suggested that one or more enterprises at the cantonal level, with previous scientific-expert study on justification of establishment, is the best solution. By doing so, implementation of benchmarking, which will show the differences between enterprises on objective manner, is assured. Representatives of local community and one cantonal ministry chose option of one enterprise at the one forest management area. They think that forest management area is one natural and economically complete area which meets requirements for assuring sustainable forest management. None of the respondents (except the director of one enterprise who was undecided and offered two answers) did not choose the option for an enterprise in the municipality (municipal enterprises).

\section{CONCLUSIONS - Zaključci}

Based on conducted research it can be concluded that all forest policy actors understand the problem of governing the forest resources and that there is high level of concordance about the defining the functional forest management. It can be seen that there is a problem of efficiency, i.e. the possibility of a positive business enterprises with regard to the different resource base. Almost all interest groups are consent that current model of governing the forest resources is unsatisfying. Main problem is in the separation of governing and ownership functions. Federal office transfers jurisdiction on the Cantonal office, which is consequence of unclear and inaccurate formulations in the Constitution, which leads to the fact that owner loose possibility to create common forest policy and functional governing of the forest resource. Unclearly defined vertical coordination leads to overlapping of jurisdiction and accountabilities. 
The majority of the interviewees consider independent Federal office for forests with cantonal departments (or offices whise field of authority do not need to coincide with the borders of the cantons) as the most preferred option. The advantages of the proposed model are as follows:

- Independent Federal office for forestry as central institution of forest resources governing would represented owners' interests. Therefore, it means that Federal office for forestry could, without limitation, lead common forest policy and execute the function of forest management planning.

- Federal office for forestry would transfer, by the contract, forest management activities to the FME, with the obligations to pay compensation. FME would be obligated to realize forest management plans, which would be made by the Federal office for forestry.

- Funds for the public benefit of forest functions would be collected into the common account of Federal office for forestry. This would allow easier monitoring of collection and transparent expenditure of these funds.

- Addressed problem about overlapping jurisdiction between the Federal office and Cantonal offices would be solved by establishing strong vertical coordination with clearly defined duties and responsibilities at all levels.

For ensuring sustainable forest resources management, it is necessary to meet biological, sociological and economic criteria. Since there is unequal distribution of forest resources in Federation B-H, logically different numbers of enterprises have to be formed in order to meet basic criteria. It means that, in the spatial distribution, different organizational forms of enterprises, from the municipal up to the cantonal level, may appear. For determining the number of enterprises (optimal), expert's analysis on status of existing enterprises is required. Based on analysis, study on justification of their establishment has to be done, and certainly, this is in the owner's interest apropos founder of the enterprises.

In the process of reorganization, economic analysis can confirm the status of enterprises as the most favourable organization of forest sector.

Based on respondents' attitudes with respecting the matrix interest-power of individual interest groups, two following options are possible:

- One enterprise in the F B-H (in a form of holding daughter companies that have legal status) or

- One or more enterprises at the cantonal level

In both options, minimum area for ensuring sustainable forest management is forest management area that meets economic, ecological and sociologic principles, both theoretically and practically, should become one economic entity. Mentioned economic entities, united in the holding, would have legal personality (first option). This option would mean centralization with establishment of the hierarchy in the management. Because of political reality that can be obstacle to this option, forming one or more enterprises on the cantonal level is more realistic, but with previous study on justification of a given solution. In this way, the founder (e.g. cantonal assembly) would have possibility to monitor the business indicators per enterprises, apropos 
implementation of continuous benchmarking in order to improve business performance.

\section{REFERENCES - Literatura}

DELIĆ, S. (2009): Posljedice praktične primjene zakonskih odredbi o finansiranju biološke reprodukcije u FBiH, Naše šume, UŠIT, Broj 14-15, Sarajevo

Delić, S., Avdibegović, M. (2009): Prihodi i troškovi proizvodnje u šumarstvu Federacije Bosne i Hercegovine, Radovi Šumarskog fakulteta, broj 2, Knjiga $\mathrm{XL}$, Sarajevo

FSC nacionalni standardi za Bosnu i Hercegovinu, draft verzija

FIGURIĆ, M. (1996): Uvod u ekonomiku šumskih resursa, Sveučilište u Zagrebu, Šumarski fakultet, Zagreb

Improved Pan-European Indicators for Sustainable Forest Management, MCPFE Expert Level Meeting, 2002, Vienna, Austria

Informacija o gospodarenju šumama u Federaciji $\mathrm{BiH}$ u 2009. godini i planovi gospodarenja za 2010. godinu, Federalno ministarstvo poljoprivrede, vodoprivrede i šumarstva, Sarajevo, 2010.

Izvještaj o realizaciji projekta „Istraživanje cijene gospodarenja šumama i šumskim zemljištima na području Federacije Bosne i Hercegovine“, (2008), Šumarski fakultet, Sarajevo

JovIĆ, P., Jovıć, D. (2010): Elaborat participativnog procesa izrade šumarskog programa Federacije Bosne i Hercegovine, draft

SABADI, R. (1992): Šumarska politika, Hrvatske šume, Zagreb

Uredba o šumama, Službene novine FBiH broj 83/09, 2009. godine

Zakon o šumama, Službene novine FBiH broj 20/02, 2002. godine 


\section{SAŽETAK}

U ovom radu je analiziran trenutni model upravljanja šumama i organizacije šumarskog sektora u Federaciji BiH. U cilju definisanja funkcionalnog modela upravljanja šumskim resursima u $\mathrm{FBiH}$, kao i efikasnog i efektivnog organizacionog modela preduzeća šumarstva provedena su kvalitativna istraživanja na osnovu kojih su putem direktnog intervjuisanja dobiveni stavovi i mišljenja svih važnijih aktera šumarske politike o ovim pitanjima.

Pri davanju ocjene trenutnog modela upravljanja šumskim resursima, sve interesne grupe su u potpunosti saglasne da je on nezadovoljavajući. Osnovni problem koji je identifikovan jeste odvajanje funkcije upravljanja od funkcije vlasništva. Federalna uprava prenosi svoje nadležnosti na kantonalne uprave, što je posljedica nejasnih i nepreciznih formulacija u Ustavu, tako da vlasnik gubi mogućnost kreiranja jedinstvene šumarske politike i funkcionalnog upravljanja ovim resursom. Nejasno definisana vertikalna koordinacija dovodi do preklapanja nadležnosti i odgovornosti.

$\mathrm{Na}$ osnovu ponuđenih modela upravljanja, većina ispitanika smatra da je samostalna Federalna uprava za šumarstvo izvan FMPVŠ, koja bi imala svoja kantonalna odjeljenja (ili ispostave koje se ne moraju poklapati sa granicama kantona) najprihvatljivija opcija. Prednosti takvog modela se ogledaju u mogućnosti samostalne Federalne uprave da zastupa interese vlasnika i vrši centralnu funkciju upravljanja šumskim resursima. Na taj način bi mogla bez ograničenja voditi jedinstvenu šumarsku politiku i izvršavati funkciju planiranja gospodarenja šumama. Federalna uprava bi putem ugovora prenosila gospodarenje šumama na ŠPD uz obavezu plaćanja određene naknade. Problem oko preklapanja nadležnosti Federalne uprave i kantonalnih odjeljenja (ispostava) bio bi rješen uspostavom jake vertikalne koordinacije uz jasne obaveze i odgovornosti na svim nivoima.

Iz analize trenutne organizacije sektora šumarstva se može zaključiti da je potrebna njegova reorganizacija. Reorganizaciju treba provesti na osnovu ekonomske analize opravdanosti osnivanja preduzeća pri čemu bi se u svakom konkretnom slučaju identifikovali ključni problemi i u skladu sa njima tražila odgovarajuća rješenja. Minimalna površina na kojoj se može osigurati održivo gospodarenje je šumskoprivredno područje formirano na ekološkim, ekonomskim i sociološkim kriterijima. Na osnovu stavova interesnih grupa a uz uvažavanje političke realnosti u $\mathrm{FBiH}$, formiranje jednog ili više preduzeća na kantonalnom nivou bi bila najpovoljnija opcija organizacije šumarskog sektora. 